\title{
Jacek Bartyzel
}

\section{Fatalne nieporozumienie: nacjonalizm czy nacjonalitaryzm?}

Uderzającą cechą współczesnego języka politycznego jest nagminne nadużywanie pojęcia „nacjonalizm” - i odpowiedzialnością za tę sytuację nie można obciążać wyłącznie massmediów, rządzących się prawem błyskawiczności i komunikatywności przekazu, a nie nakazem precyzji teoretycznej. Moralne pograżanie nacjonalizmu, wskutek nieustannego obciążania go odpowiedzialnością za wszystko zło (jak „czystki etniczne" w b. Jugosławii, rzezie międzyplemienne w Rwandzie, terroryzm separatystów baskijskich czy korsykańskich, zamachy bombowe radykalnych islamistów i hinduistów, konflikt izraelsko-palestyński) dziejące się w świecie z powodu stosowania ,zasady narodowościowej" i ,prawa do samostanowienia" każdej grupy etnicznej, jaka uzna za stosowne i korzystne określić się jako „naród”, dokonywane jest jednak nie tylko przez dziennikarzy, korzystajaccych bezrefleksyjnie $\mathrm{z}$ aparatury pojęciowej, którą mają ,pod ręką", lecz również przez tych, którzy tę aparaturę wytworzyli i z konsekwencją godną lepszej sprawy podtrzymuja, to znaczy także akademickich badaczy doktryn politycznych, a w każdym razie przez pokaźny ich zastęp. Ich wina zatem jest większa, ponieważ jako historycy mający dostęp do źródeł i poważnej literatury przedmiotu muszą wiedzieć, że obie wskazane wyżej zasady były przez nacjonalizm sensu stricto kategorycznie potępiane. W konsekwencji, „przeciążanie” pojemności terminu ,nacjonalizm” prowadzi nawet do tak absurdalnych pseudoteoretyzacji, jak wymyślanie quasi-bytu ideologiczno-politycznego pod nazwą ,nacjonalizmu pokomunistycznego" lub postrzeganie w nacjonalizmie „najwyższego stadium komunizmu". Jako panaceum na to zaciemnienie proponujemy niżej powrót do 
zapomnianego pojęcia „,nacjonalitaryzm”, stworzonego właśnie dla odróżnienia egalitarnych ideologii, głoszących etniczno-językową i/albo rasową ,zasadę narodowościową", od autentycznej doktryny nacjonalizmu, uznającego państwo za suwerena i formę bytu ,narodu historycznego", niekoniecznie homogenicznego rasowo, etnicznie i językowo.

\section{Pojęcie nacjonalitaryzmu}

Twórca terminu „nacjonalitaryzm” był francuski pisarz polityczny, bliski nacjonalistyczno-rojalistycznej Action Française, René J o h a n n e t (1884-1972), który zaproponował go w wydanej po raz pierwszy ${ }^{1}$ w 1918 r. książce Zasada narodowościowa (Le principe des nationalités). Dla zrozumienia pobudek, które kierowały autorem tego neologizmu, należy wziąć pod uwagę kilka istotnych, kontekstualnych okoliczności:

1) proklamowanie, jeszcze w epoce oświecenia, przez Jeana-Jacquesa Rousseau'a zasady „suwerenności ludu” (souveraineté du peuple), przeciwstawionej suwerenności królów, uznanych za „przywłaszczycieli” władzy należnej ludowi, który jest nosicielem wszelkiej suwerenności (toute souveraineté réside dans le peuple);

2) dokonane przez rewolucjonistów francuskich utożsamienie suwerennego „ludu" z „,narodem" (le peuple = la nation), z którego wszelako wykluczeni zostali wszyscy „niepatrioci”, czyli kler i ,arystokraci”, ex definitione niegodni bycia "dziećmi (Matki-) Ojczyzny” (les enfants de la Patrie), jak również proklamowanie i rozpoczęcie przez rewolucję francuska, kontynuowanej przez Cesarstwo Francuskie, zewnętrznej „wojny rewolucyjnej” (,pokój chatom, wojna pałacom”), pod hasłem wyzwolenia ludów, choćby wbrew ich woli, z „tyranii” królów i „zabobonów” religijnych;

3) rozprzestrzenianie się w całej XIX-wiecznej Europie, a zwłaszcza: a/ na obszarach jednolitych etnicznie i językowo, lecz zróżnicowanych państwowo (jak Niemcy i Włochy), b/ dawnych państwach pozbawionych niepodległości (jak Polska, Chorwacja czy Irlandia) oraz c/ pośród szczepów etnicznych, kreowanych jako narody przez litera-

${ }^{1}$ Drugie wydanie ukazało się w $1923 \mathrm{r}$. 
tów romantycznych, wymyślających im państwową genealogię (jak Ukraińcy czy Finowie), ,z a s a d y n a r o d o w o ś c i o w e j", przeciwstawionej zasadzie monarchicznego legitymizmu i mającej usprawiedliwić ich dążenia zjednoczeniowe lub irredentystyczne;

4) pojawienie się $w$ drugiej połowie XIX w. oraz rychłą zmianę znaczenia pojęcia ,nacjonalizm”.

Konsekwencją wewnątrzpaństwową (najskrupulatniej zrealizowaną we Francji) koncepcji suwerenności ludu/narodu była likwidacja - na rzecz niezróżnicowanej i ujednoliconej w prawach masy jednostek „obywateli” (citoyens) - wszelkiego pluralizmu, zarówno stanowego i korporacyjnego, jak samorządowego i prowincjonalnego oraz powstanie scentralizowanej republiki ,jednej i niepodzielnej" (une et indivisible).

Zalążki ideologicznego uzasadnienia „zasady narodowościowej” dał już cesarz $\mathrm{N}$ a p o l e o n I, tyle że ex post, w pamiętnikach pisanych jako zdetronizowany więzień Anglików na Wyspie św. Heleny, usprawiedliwiając swoje podboje pragnieniem zbudowania uniwersalnej wspólnoty, w której ramach wszystkie nacje odzyskają swoje słuszne prawa. Interpretację tę wznowił jego bratanek, książę Ludwik-Napoleon Bonaparte, w wydanej w 1839 r. książce Des idées Napoléoniennes, który następnie, już jako cesarz $\mathrm{N}$ a p o l e o n III, podniósł tę zasadę do rangi programu swojej polityki zagranicznej, praktycznie wcieliwszy ja w życie jedynie na obszarze Włoch, zjednoczonych dzięki jego wsparciu. Kolejnym, milowym krokiem w uczynieniu tej zasady podstawa ładu międzynarodowego była, wyartykułowana w 1917 r., w planie pokojowym, znanym pod potoczną nazwą „14 punktów” prezydenta USA, Woodrowa W i 1 s o n a, doktryna ,samostanowienia narodów”, która stała się podstawą rekonstrukcji mapy politycznej Europy przez Kongres Wersalski i ideologiczną podbudową Ligi Narodów.

Ogólnie, realizacja „zasady narodowościowej” przebiegała w dwu kierunkach, wchodzących w stale i powszechnie obserwowaną konfrontację; $\mathrm{z}$ jednej strony, narody stanowiące etniczny trzon danego państwa i uważające je za wyłącznie „swoje” państwo narodowe starają się środkami administracyjnymi, poprzez ujednoliconą edukację państwowa, a niekiedy i siłą fizyczną - ujednolić państwo narodowościowo oraz wykorzenić wszelkie odrębności, nieprzystające do jednolitego wzorca. Z drugiej strony, tzw. mniejszości etniczne - powołując się na tę samą 
„Zasadę narodowościowa” oraz „prawo do samostanowienia” - usiłuja wywalczyć jak najszerszy zakres swoich partykularnych uprawnień, nie stroniąc przy tym od odwoływania się do innych państw, zwłaszcza tych, w których ich narodowość ma pozycję dominująca, albo do instancji ponadpaństwowych, częstokroć przejawiają tendencje separatystyczne, a nawet irredentystyczne, w wielu wypadkach uciekając się także do zbrojnych rebelii albo do terroryzmu. Na przykład, jak zauważa Johannet, po uzyskaniu niepodległości Czesi natychmiast postawili sobie za punkt główny polityki narodowej niewywiązanie się z uroczystych zapewnień dania w Czechosłowacji równouprawnienia Słowakom, Finowie uznali za niezbędne wyrugowanie Szwedów i języka szwedzkiego, a Polska stanęła oko w oko z separatyzmem Rusinów i Litwinów ${ }^{2}$. Ta nieustająca konfuzja wypływa $\mathrm{z}$ niemożliwości obiektywnego ustalenia, na gruncie ,zasady narodowościowej”, jaką grupę ludzką można uznać za naród, której narodowości przysługuje ,prawo do samostanowienia" - aż do oderwania się od państwa, w którym jakaś część jej członków zamieszkuje, i utworzenia własnego państwa.

Powyższej sprzeczności nigdy nie zdołały rozwiązać nie tylko oficjalne doktryny oraz działania mężów stanu czy instytucji międzynarodowych, ale również próby teoretyzacji pojęcia principe des nationalités. Definicje „zasady narodowościowej”, z których pierwszą („,...to zasada, wedhug której każda rasa ludzka dąży do ukonstytuowania się jako samodzielny organizm polityczny") sformułował ${ }^{3}$ w 1835 r. pozytywista Émile L i t tr é (1801-1881), a rozwijał", między inymi, pierwszy liberalny premier II Cesarstwa - Émile O 11 i v i e r (1825-1913), Johannet ujmuje zbiorczo jako postulat, ,ażeby pomiędzy państwem a narodowością zachodziła zgodność", toteż ,jedynym państwem, które ona chce uznać, jest państwo narodowe (état national), którego granice wyznaczane są nie według biegu rzek, kierunku gór, przypadków siły (les hasards de la force) lub układów dyplomacji, lecz według rozsiedlenia ras, a raczej narodowości"s. Jest to jednak wymóg praktycznie nierealizowalny, ponieważ rasy są przemieszane wszędzie, a narodowości prawie wszędzie, toteż w świetle „zasady narodowościowej” nie-

${ }^{2}$ Zob. R. Johannet, Le principe des nationalités, Paris 1918, s. XLVIII.

${ }^{3}$ Dictionnaire de l'Académie française.

${ }^{4}$ Zob. É. Ollivier, L'Empire libérale. I. Du principe des nationalités, Paris 1895.

${ }^{5}$ R. Johannet, op. cit., s. 19. 
podobna rozstrzygnać kwestię przynależności państwowej obszarów mieszanych etnicznie, albo spornych historycznie lub $\mathrm{z}$ jakichkolwiek innych powodów; nie można „obiektywnie" i w sposób satysfakcjonujący wszystkie strony ustalić, czy Alzacja jest francuska czy niemiecka, Wileńszczyzna polska czy litewska, Siedmiogród węgierski czy rumuński, a Kosowo serbskie czy albańskie, ani ,sprawiedliwie” zdecydować do jakiego państwa ziemie te „powinny” należeć. We wszystkich takich przypadkach wzrasta natomiast zawsze obustronna nienawiść, ponieważ zwiększają się ,powierzchnie tarcia”, czego nieuchronnym skutkiem jest „wojna co rok, i na każdym kroku”6.

Dysjunkcji pomiędzy nacjonalitaryzmem a nacjonalizmem nie rozwiązało także samo pojawienie się pojęć „nacjonalizm” (nationalisme) i „,nacjonalista" (nationaliste), ponieważ pierwszy odnotowany przypadek ich użycia ${ }^{7}$ - przez liberała Luciena P r é v o s t - P a r a d o 1 a (1829-1870) - został odniesiony właśnie do „zasady narodowościowej”. Prawdziwym przełomem było dopiero wznowienie tych pojęć w $1892 \mathrm{r}$. przez Maurice’a B a r r è s a (1862-1923), w manifeście La querelle des nationalistes et des cosmopolites ${ }^{8}$, będącym pierwszą artykulacją doktryny nacjonalistycznej sensu stricto. W znaczeniu użytym przez Barrčsa nacjonalizm jest ,partią Francji”, jako „,narodu-państwa” ( $\mathrm{Na}$ tion-État), zaś naród to organizm polityczny, którego odwieczną zasadą była wierność suwerenowi i dynastii narodowej oraz instytucjom tradycyjnym. Ponieważ jednak nierozumni Francuzi zabili swojego króla, odrzucili swoją dynastię i zniszczyli instytucje tradycyjne, nadrzędnym celem nacjonalizmu staje się odbudowanie jedności narodowej, ocalenie narodowego dziedzictwa i przywrócenie instytucji tradycyjnych. W konsekwencji, rzeczą nacjonalizmu jest odnoszenie każdej kwestii politycznej do interesu narodu-państwa, w przeciwieństwie do ideologii kosmopolitycznych, które kwestie te rozpatrują w świetle interesów albo (jak liberalizm) jednostki, albo (jak marksizm) proletariatu. Od wystapienia Barrèsa zatem, pojęcie nationalisme „oznacza zwolennika polityki ściśle narodowej (il signifie partisan d'une politique strictement

\footnotetext{
${ }^{6}$ Ibid., s. XLVIII.

${ }^{7} \mathrm{~W}$ broszurze Anciens partis, Paris 1860.

8 „Le Figaro”, 4 VII 1892.
} 
nationale)"9.

Zarówno (jeszcze republikański) nacjonalizm Barrèsa i (już rojalistyczny) nacjonalizm ,integralny" Charlesa M a u r r a s a (18681952), jak pokrewne im, a najbardziej dojrzałe doktrynalnie, zwłaszcza w krajach romańskich, nacjonalizmy tradycjonalistyczne (nacjonalizm włoski Enrica Corradiniego, hiszpański „nacjonal-katolicyzm” Ramira de Maeztu i frankizm, portugalski ,integralizm luzytański”' i salazaryzm) zdecydowanie odrzucały i teorię „suwerenności narodu”, i „zasadę narodowościowa""10. Właśnie ten pozorny paradoks ,nacjonalizmu nienarodowościowego" legł u podstaw, odczuwanej przez Johanneta, konieczności utworzenia pojęcia ,nacjonalitaryzm”, delimitującego te dwie nie tylko różne, ale wręcz przeciwstawne sobie doktryny. Termin ten przejął i doprecyzował Maurras, a w następnym pokoleniu nacjonalistów - Jacques P lo n c a r d d'Assac (1910-1998).

\section{Odmiany nacjonalitaryzmu}

Przeciwieństwo nacjonalitaryzmu i nacjonalizmu należy rozpatrywać uwzględniając tę okoliczność, że o ile nacjonalizmy (w sensie zainaugurowanym manifestem Barrèsa), mimo iż miały swoje cechy specyficzne (,narodowe") w różnych krajach, to jednak były bardzo do siebie podobne (i, co równie ważne, zadzierzgały się pomiędzy nimi więzy sympatii), nadto okres ich rozkwitu był względnie krótki (zasadniczo pierwsza połowa XX w.), o tyle historia nacjonalitaryzmu (choć nigdy pod tą nazwa) ma już ponad dwa stulecia, toteż występował on, i występuje nadal, w wielu odmianach, nieodmiennie sobie wrogich, zarówno pomiędzy odcieniami ideologicznymi, jak narodowościami, w których imieniu działa. Wielość nurtów nacjonalitaryzmu można, w pewnym koniecznym uproszczeniu, sprowadzić do dwu zasadniczych odmian: 1) nacjonalitaryzmu demokratycznego bądź demoliberalnego oraz 2) nacjonalitaryzmu plemienno-rasowego, który w pierwszej połowie XX w. znalazł ujście (w symbiozie $\mathrm{z}$ socjalizmem) w faszyzmie, a zwłasz-

\footnotetext{
${ }^{9}$ R. Johannet, op. cit., s. 18.

${ }^{10}$ Szerzej o nich zob. w mojej książce Umierać, ale powoli!. O monarchistycznej i katolickiej kontrrewolucji w krajach romańskich 1815-2000, s. 444-846.
} 
cza w niemieckim nazizmie. Dla obu odmian nacjonalitaryzmu niezmiernie ważne było wszelako przejście przez kulturową fazę romantyzmu, co nadało im piętno quasi-mistycznej egzaltacji „czystej duszy” prostego ludu/narodu, a to w sposób zasadniczy różnicuje też metapolitykę nacjonalitaryzmu i nacjonalizmu, który w każdym wypadku wychodził od gruntownej krytyki romantyzmu.

\section{Nacjonalitaryzm demokratyczny}

Demokratyczna odmiana nacjonalitaryzmu opiera się na doktrynie suwerenności ludu/narodu, uznawanego za jedyne źródło prawomocności władzy, która wyraża ,wolę ludu”, przy czym w ujęciu „czysto” demokratycznym (russowskim) jest to „wola powszechna” (volonté générale), przejawiana głosem całego ludu/narodu i bezpośrednio, natomiast w wersji demoliberalnej lud/naród stanowi arytmetyczny zbiór jednostek, mogący swoją wolę objawiać pośrednio, delegując w akcie wyborczym suwerenność (délégation de souveraineté) na swoich przedstawicieli. W każdym wypadku oznacza to jednak rząd (,zwierzchnictwo") niezróżnicowanej „masy” ludu/narodu, toteż konsekwencją nacjonalitaryzmu jest pasja zrównywania (egalitaryzm). Skoro cały naród jest suwerenem, to nie można tolerować żadnego zróżnicowania przywilejów i obowiązków poszczególnych stanów, korporacji, municypiów czy prowincji; wszyscy muszą mieć takie same prawa i obowiązki, albo, inaczej mówiąc, identyczną porcję praw i obowiązków. Nie wolno tolerować również, w ramach państwa jednego narodu, pluralizmu etniczno-językowego: nie ma już Bretończyków czy Prowansalczyków, tylko Francuzi mówiący ,językiem republikańskim"; nie ma już Saksończyków, Bawarów czy Szwabów, są tylko Niemcy. W reakcji na ten stan rzeczy, pośród członków społeczności żyjących przez wieki bez poczucia dysharmonii pomiędzy byciem jednocześnie, mówiącym językiem okcytańskim Prowansalczykiem i Francuzem, to znaczy poddanym króla Francji, albo Baskiem, mówiącym językiem euzkera i Hiszpanem, to znaczy poddanym króla Hiszpanii, rodzi się poczucie poniżenia, dystansu, a wreszcie dążenie do separacji i utworzenia własnego państwa - w którym sam będzie mógł upodabniać do siebie innych analogiczną metodą. Maurras wyśmiewał wręcz także tych „fałszywych nacjonali- 
stów" (resp. nacjonalitarystów), którzy co najmniej z nieufnością odnosili się do katolicyzmu i Watykanu, dlatego, że papież był dla nich „Włochem"ll.

Na zewnątrz natomiast, nacjonalitaryzm tego typu przyjmuje jednocześnie dwie, wchodzące ze sobą w wewnętrzny konflikt, dyrektywy, wynikające $z$,zasady narodowościowej”, to jest równość wszystkich narodów oraz nakaz zjednoczenia w ramach jednego państwa wszystkich prowincji, w których dana narodowość przeważa liczbowo. Dążenie takie musi jednak zawsze zderzyć się $\mathrm{z}$ analogicznym dążeniem tej nacji, która w spornej prowincji stanowi wprawdzie mniejszość, ale jej elita przywódcza także kieruje się pragnieniem zjednoczenia wszystkich członków swojej narodowości w ramach jednego państwa. Jak pokazują przykłady dwóch głównych procesów unifikacyjnych, które zaszły w XIX-wiecznej Europie, tj. we Włoszech i w Niemczech, jednoczenie terytorium narodowego oparte o powyższe przesłanki, łączy się koniecznie $\mathrm{z}$ dwoma zjawiskami: pogwałceniem legitymizmu państwowo-dynastycznego pochłanianych organizmów z danego obszaru etniczno-językowego oraz zastosowaniem procedur celowego wynaradawiania członków narodowości nie wchodzących do tej grupy etnicznej, ale żyjących na jej obszarze państwowym (np. Austriaków we włoskim Trydencie, czy Polaków w zaborze pruskim i Duńczyków w SzlezwikuHolsztynie). Cechą charakterystyczną nacjonalitaryzmu (zwłaszcza przesiąkniętego mentalnością romantyczna) jest nie tylko ignorowanie ,zastanych" tożsamości historycznych w anektowanych prowincjach (na przykład Neapolitańczyków czy Hanowerczyków), ale przechodzenie do porządku nad uświadamianym sobie faktem nieistnienia w rzeczywistości narodu, w którego imieniu nacjonalitaryzm ten działa. Prowadzi go to do woluntaryzmu, który wyobraża sobie, że naród można „wykreować", czego wymownym świadectwem jest słynne wyznanie jednego z promotorów włoskiego Risorgimenta, Massima Taparellego markiza d 'A z e g l i o (1798-1866), uczynione tuż po aneksji całej Italii przez Piemont: ,zrobiliśmy Włochy, a teraz musimy zrobić Włochów”12.

\footnotetext{
${ }^{11}$ Zob. Ch. Maurras, La politique religieuse, [w:] id., La Démocratie religieuse, Paris 1921 , s. 340 (z tego samego powodu nacjonalitarystą należy zatem nazywać tego, który dzisiaj „kocha” papieża dlatego, że jest on „Polakiem”).

${ }^{12}$ Ironią historii jest to, że - dowodzący „niezrobienia”. Włochów do dzisiaj - separatyzm rozkwita aktualnie nie na podbitym Południu, lecz na podbijającej Północy.
} 
W jeszcze bardziej irracjonalnej postaci ten woluntaryzm nacjonalitaryzmu przejawił się w ukutym przez Niemców pojęciu ,narodowości nieświadomej", co przywódcy Partii Narodowo-Liberalnej, Heinrichowi von Tre it s c h ke (1834-1896), pozwoliło powiedzieć o Alzatczykach: „Chcemy oddać im ich własne jestestwo, choćby nawet wbrew ich woli"'3.

Dla nacjonalizmu wszystkie te roszczenia nacjonalitaryzmu są z gruntu fałszywe. Nade wszystko, absurdem jest dla niego nacjonalitarny woluntaryzm; nie może być nacjonalizmu bez już ukształtowanego narodu, który jest dziełem geografii i historii oraz wielowiekowej, narodotwórczej roli państwa. To „40 królów stworzyło Francje”, jak mawiał Maurras, natomiast nie da się „zrobić” narodu jednym dekretem czy plebiscytem. Nacjonalizm przychodzi zawsze po narodzie; to miał na myśli Barrès pisząc, że ,nacjonalizm jest akceptacją pewnego determinizmu"14 - czyli determinizmu geografii i historii. Wyklucza to także opieranie polityki narodowej na trzymaniu się etniczno-językowej ,zasady narodowościowej”. Obszar i granice państwa winny być dostosowane do jego żywotnych potrzeb oraz uwarunkowań naturalnych; na przykład dla Francji granicami bezpieczeństwa, i naturalnymi zarazem, są z jednej strony Pireneje, a z drugiej linia Renu. Jej interesowi narodowemu nie stoi na przeszkodzie fakt, że będzie to oznaczało zarówno znalezienie się na jej obszarze pewnej liczby ludności etnicznie niemieckiej czy włoskiej, jak pozostanie w Belgii czy Szwajcarii pewnej liczby ludności etnicznie francuskiej. W przeciwieństwie do nacjonalitarysty nacjonalista nie będzie jednak zmuszał niemieckojęzycznego Alzatczyka, czy włoskojęzycznego Sabaudczyka, do posługiwania się językiem francuskim - wystarczy mu ich lojalność wobec Francji i jej „arcychrześcijańskiego króla” (le roi trčs-chrétien), a tym samym przynależność do narodu nie jako homogenicznej etnii, lecz jako politycznej „wspólnoty przeznaczenia”. Podobnie, hiszpańskiego karlistę nie będzie martwić rozmaitość języków, obyczajów, przywilejów lokalnych (fueros) Basków czy Katalończyków, pod warunkiem ich wierności wobec wspólnej Monarquía Hispánica i jej „króla katolickiego” (el rey católico). Bodaj najdalej poszła w tym kierunku, przyjęta w Portugalii

${ }^{13}$ Cyt. za: R. Johannet, op. cit., s. 211.

${ }^{14}$ M. Barrès, Scènes et doctrines du nationalisme, Paris 1925, s. 10. 
Salazara, doktryna „luzotropikalizmu”, sformułowana zreszta przez brazylijskiego socjologa, Gilberta de Mello F r e y r e (1900-1987), która zakładała transkontynentalną i multirasową solidarność wszystkich Luzytańczyków, to jest Portugalczyków, Brazylijczyków oraz Afrykanów, Azjatów i Indian ze wszystkich dawnych i aktualnych prowincji zamorskich.

Nacjonalizm opowiada się w ogóle raczej za mniejszą ilością państw dużych (lecz szanujących odrębności lokalne) i zdolnych do samodzielnej egzystencji, niż ich rozdrabnianiem podług ,zasady narodowościowej”, któremu nigdy nie ma końca. Swego rodzaju „kamieniem probierczym", pozwalającym w czasie i po I wojnie światowej odróżnić nacjonalitarystę od nacjonalisty, był stosunek do wielonarodowej monarchii habsburskiej. Podczas gdy nacjonalitaryści wszystkich odcieni postanowili (neojakobin Georges Clemenceau, demokrata Woodrow Th. Wilson, liberał postępowy David Lloyd George i liberał konserwatywny Vittorio Emmanuele Orlando) o jej rozbiorze, albo wyrażali z tego powodu satysfakcję (demokrata Tomáš Garrigue Masaryk, nacjonal-socjalista Adolf Hitler), nacjonaliści równie jednomyślnie wyrażali żal z powodu upadku ostatniego w Europie państwa reprezentującego zasadę legitymistyczną (i katolickiego).

Nacjonalizm różnią też od nacjonalitaryzmu fundamentalne zasady ideowo-ustrojowe. Nacjonalista nie uznaje zasady „suwerenności narodu", ponieważ nie jest on egalitarysta, a naród nie stanowi dla niego ani masy, ani sumy jednostek aktualnie żyjącego (i głosującego w wyborach) pokolenia. Nacjonalista „integralny”, jak Maurras, będzie stale podkreślał, że „zło (...) idei nacjonalitarnej nie pochodzi z nacjonalizmu, lecz z wszczepienia narodom idei równości"'15. Ustrojowo, zasada nacjonalistyczna nie jest narodowościowa i demokratyczna, tylko państwowa i najczęściej monarchiczna, albo przynajmniej (jak u Barrèsa) autorytarna i elitarystyczna. Dla nacjonalizmu suwerenem nie jest naród, tylko państwo personifikowane przez „szefa", toteż naród jest w nim pojmowany, jako odpowiednik państwa, czy to dlatego, że przedstawia państwo, co znikło, lub państwo istniejące, lub wreszcie dąży do stworzenia państwa w przyszłości"16.

${ }^{15}$ Ch. Maurras, Votre bel aujourd'hui, Paris 1953, s. 238.

${ }^{16}$ R. Johannet, op. cit., s. 405. 
W doktrynie nacjonalizmu naród nie jest, i nie może być, suwerenem także dlatego, że stanowi on wspólnotę wielopokoleniową, obejmującą - oprócz żyjących - generacje już minione i te, które dopiero się narodzą; głosów przodków i nienarodzonych jeszcze potomków nie można „zliczyć”, lecz należy je „zważyć”. Dla nacjonalisty naród jest dziedzictwem historii, którego nie wolno roztrwonić, i ,wspólnotą przeznaczenia". Dziedzictwo to winno być kontynuowane i przekazane (tradere) dalej. W słynnym adagium Barrèsa naród to „wspólne posiadanie starożytnego cmentarza i pragnienie zachowania go niepodzielnym"; naród to „ziemia i umarli” (la terre et les morts) ${ }^{17}$. Nacjonalizm jest zatem $\mathrm{z}$ istoty zachowawczy, czyli tradycjonalistyczny, zaś tym, na którym spoczywa główny ciężar ,przekazania”, jest suwerenny traductor i „zachowawca" (conservator) narodu.

\section{Nacjonalitaryzm etniczny}

Nacjonalitaryzm plemienno-rasowy, zwłaszcza w skrajnie rasistowskiej wersji niemieckiego $\mathrm{n}$ a z i z $\mathrm{m} \mathrm{u}$, w obiegowym mniemaniu uchodzi za całkowite przeciwieństwo demokracji, a tym samym za pogwałcenie demokratycznej ,zasady narodowościowej”. Jest to pogląd podtrzymywany przez niezliczonych dziś propagandystów ustroju demoliberalnego, ale daleki od prawdy. W rzeczywistości, zarówno o całej tej odmianie nacjonalitaryzmu, jak o narodowym socjalizmie w szczególności, można powiedzieć, że są one z pewnością antyliberalne (a tym samym istotnie sprzeczne $z$ liberalną odmianą demokracji), ale nie antydemokratyczne ${ }^{18}$. Sytuują się one w nurcie nazwanym przez Jacoba L. Talmona „demokracją totalitarną"19, wcieloną w życie po raz pierwszy przez francuski jakobinizm. Już sama cecha tak znamienna dla więk-

\footnotetext{
${ }^{17}$ Sformułowanie użyte po raz pierwszy w tytule i treści trzeciej konferencji publicznej Ligi Ojczyzny Francuskiej 10 marca 1899 r.

${ }^{18}$ Zob. N. Bończa-Tomaszewski, Demokratyczne źródla faszyzmu, Fronda 1998, nr $15 / 16$, s. $155-164$.

${ }^{19}$ Zob. J. L. Talmon, The Origins of Totalitarian Democracy. Political Theory and Practice during the French Revolution and beyond, London 1986 [przekład polski / fragment/: O demokracji totalitarnej, thum. W. Buchner, Znak 1992, nr 443, s. 67-80].
} 
szości niemieckich ideologii narodowych, jak żywiący się przeświadczeniem o wyższości własnego narodu na każdym polu i nienawiścią do innych narodów s z o w i n i z m, ujawniony od Germanii i Europy ${ }^{20}$ Ernsta Moritza A r n d t a (1769-1860), był rewersem szowinizmu jakobińskich ,patriotów roku II" i wiarusów Wielkiej Armii Napoleona.

W nacjonalitaryzmie plemienno-rasowym, najczęstszym w Niemczech, nie została przeto odrzucona ani demokratyczna zasada suwerenności ludu/narodu, ani principe des nationalités, tylko obie one zostały w szczególny sposób zreinterpretowane. Pierwsza została scedowana na charyzmatycznego „wodza” (Führer), uzyskującego demokratyczną legitymację przez spontaniczne acclamatio ludu; druga natomiast została przeniesiona $\mathrm{z}$ sumy jednostek-obywateli na grupę czysto rasową ${ }^{21}$. Łącznie wytwarza to egalitarną i ,przezwyciężającą" zarówno tradycyjne (stanowe, krajowe, dynastyczne) partykularyzmy, jak demoliberalny nieład, jedność Rzeszy-Ludu-Wodza (ein Reich, ein Volk, ein Führer). Hitler był niewatpliwie wrogiem liberalizmu i parlamentaryzmu, ale nie demokracji, ponieważ nienawidził monarchii i arystokracji, a stworzoną przez siebie Rzeszę nazywał ,prawdziwą demokracją niemiecką", w której wódz wyraża „wolę powszechną" zrównanego w „braterstwie” ludu/narodu (Volk); jeśli odjać partykularne dookreślenie: „niemiecka”, jest to ideał ustrojowy Rousseau’a.

Charakter „nacjonalitarny” nie był przy tym jakimś wyjątkowym przypadkiem, związanym tylko $z$ hitleryzmem, lecz immanentną oraz dominującą cechą większości nurtów myśli narodowej w Niemczech od oświecenia (Johann Gottfried Herder) i romantyzmu (Johann Gottlieb Fichte). W XIX w., zarówno nacjonalitaryzm demoliberalny, kulminujący w obradach Parlamentu Frankfurckiego (1848/49), jak postromantyczny ruch ;,volkistowski” (völkisch) i ,niemiecko-chrześcijański” (Paul de Lagarde, Karl Fischer, Arthur Dinter), były antylegitymistyczne, antyhabsburskie, wrogie uniwersalistycznej tradycji Świętego Cesarstwa, a tym samym antykatolickie i antyrzymskie. Korzenie nacjonalitaryzmu niemieckiego sięgaja zatem rewolucji religijnej luteranizmu, który z kolei, według Maurrasa, spojony jest dobrze dopasowaną obręczą ido-

${ }^{20}$ Zob. E. M. Arndt, Germanien und Europa, Altona 1803.

${ }^{21}$ Zob. K. Stojanowski, „Niemiecka masa”-zalożenia doktryny rasowej nordycznej a niemieckiej, Toruń 1935. 
latrycznego germanizmu $\mathrm{z}$ saskim poganinem Arminiusem ${ }^{22}$. Charakterystyczną cechą $\mathrm{v}$ o $1 \mathrm{k} \mathrm{i} \mathrm{z} \mathrm{m} \mathrm{u} \mathrm{było} \mathrm{także,} \mathrm{typowe} \mathrm{dla} \mathrm{nacjonalitary-}$ $\mathrm{zmu}$, odrywanie pojęcia lud/naród (Volk) od państwa, a wiązanie go z panteistycznie uwielbioną Przyroda (,tożsamością kosmologiczną,, wedhug określenia George`a L. Mosse`a ${ }^{23}$ ) oraz niechęć do pojęcia $\mathrm{Na}$ tion, uważanego za wytwór francuski.

Wytworem hitleryzmu nie był również r a s i z m sensu stricto, który acz sformułowany jako quasi-naukowa teoria antropologiczna przez Francuza Josepha-Arthura de Gobineau oraz przez naturalizowanego w Niemczech Anglika Houstona Stewarta Chamberlaina, wyjatkowo podatny grunt znalazł już w XIX w. właśnie w nacjonalitaryzmie niemieckim: „Hitler jest produktem nacjonalitaryzmu XIX-wiecznego”24.

Idea „czystości rasowej” stanowi kolejny punkt jaskrawo delimitujący nacjonalitaryzm tej odmiany od nacjonalizmu. $\mathrm{Z}$ punktu widzenia nacjonalisty théorie racique jest zarazem ghupia i niebezpieczna, bo destrukcyjna dla narodu, jako wielorasowej (pluriraciale) wspólnoty historycznej. Na przykład, naród francuski jest zlepkiem ras, uformowanym $\mathrm{z}$ celtyckich Galów, Latynów, germańskich Franków, Burgundów i Alemanów etc.; Hiszpanie to mieszanka Celtiberów, Rzymian, Gotów, Maurów i Żydów; także Niemcy zreszta, zwłaszcza w swoim wyjątkowo wyrazistym genotypie Prusaka, dużo zawdzięczają przymieszce bałto-słowiańskiej. Dla nacjonalitarysty rasistowskiego naród to nie ,ziemia i umarli”, lecz ,ziemia i krew” (Blud und Boten). To właśnie „determinizm rasowy doprowadził Hitlera do odrzucenia tezy pangermańskiej"25, która zakładała możliwość ,zgermanizowania” Słowian w monarchii habsburskiej. „Krew” przesłania rasiście wszystko inne, co prowadzi go do maniakalnego mierzenia czaszek i kształtu nosów, podczas gdy dla nacjonalisty „naród jest takim, jakim go uczyniły wieki (la nation telle que les sičcles l'ont faite)" "26. Dla nacjonalitaryzmu naród jest rasą antropologiczną, dla nacjonalizmu-,,rasą historyczną", to znaczy

\footnotetext{
22 Zob. Ch. Maurras, La politique religieuse..., s. 340.

${ }^{23}$ Zob. G. L. Mosse, Kryzys ideologii niemieckiej. Rodowód intelektualny Trzeciej Rzeszy, thum. T. Evert, Warszawa 1972, s. 29-76.

${ }^{24}$ J. Ploncard d'Assac, Doctrines du nationalisme, Chiré-en-Montreuil 1978, s. 203.

${ }^{25}$ Ibid., s. 224.

${ }^{26}$ R. Johannet, op. cit., 192.
} 
zachowuje się jak pewien typ psychofizyczny. W konsekwencji, „nacjonal-socjalizm nie jest nacjonalizmem. [...] Inkorporuje pewne pierwiastki [narodowe], ale podporządkowuje je czemuś innemu niż ich cel naturalny, wynaturza je i odwraca od ich głębszego znaczenia"27.

$\mathrm{Z}$ kolei włoski fa s z y z m, choć - w przeciwieństwie do nazizmu nie rasistowski, był też nacjonalitarny, a nie nacjonalistyczny, bo wyznawał „dynamiczna”, ,kreacjonistyczną” i woluntarystyczną koncepcję narodu jako ,produktu” heroicznej woli i wiary. Właśnie $z$ tego punktu widzenia, liberalno-faszystowski filozof Giovanni G e n t i l e (18751944) krytykował „błąd” nacjonalizmu, polegający na traktowaniu narodu jako „statycznego" elementu prawa natury, co ,nadaje tej doktrynie pewną twardość nieliberalnego, wstecznego, surowego konserwatyzmu, będącego elementem mniej sympatycznym"28.

Wprawdzie w obu krajach istniały ruchy autentycznie nacjonalistyczne (Associazione Nazionalista Italiana, ,konserwatywna rewolucja” w Niemczech), ale jest rzeczą znamienna, że zostały one wyparte, albo po części wchłonięte, przez nacjonalitaryzm faszystowski i hitlerowski, co ze względu na analogie rozwoju historycznego nasuwa wniosek, że przyczyna takiego stanu rzeczy była identyczna, to jest powstanie „nacjonalizmu bez narodu", a więc odwrócenie naturalnego porządku rzeczy.

\section{Nacjonalitaryzm a ,sprawa polska”}

Określenie „nacjonalitaryzm” jest najzupełniej adekwatne do całej tradycji polskich ruchów niepodległościowych i insurekcyjnych oraz demokratyczno-rewolucyjnych, od samego początku zapatrzonych w „tęczę Franków”, a także szczególnie mocno przesiąkniętych romantyzmem.

Bardziej złożona jest kwestia „,nowoczesnego" ruchu narodowo-demokratycznego (,wszechpolskiego"), potocznie zwanego e n d e c j a. Do niedawna jeszcze niemal za bezdyskusyjny pewnik uchodził pogląd o prawicowości Narodowej Demokracji oraz jej podobieństwie do nacjonalizmu francuskiego czy włoskiego. Wydaje się wszakże, że jest to

${ }^{27}$ J. Ploncard d'Assac, op. cit., s. 195.

${ }^{28}$ G. Gentile, •ródla i doktryna faszyzmu, przeł. H. Mirecka, Warszawa 1933, s. 46. 
błąd optyczny, wynikający z postrzegania całości dziejów i rozwoju ideowego obozu narodowego przez pryzmat kształtu, jaki przybrał on $\mathrm{w}$ szczytowej fazie swojej ewolucji, to jest w latach 30-tych XX wieku. Tymczasem, w swojej pierwotnej postaci nurt ten, pomimo przeprowadzenia ostrej krytyki insurekcyjnego i ,inter-nacjonalistyczego" (,za wolność waszą i naszą") patriotyzmu ,starej daty” oraz antyliberalizmu i antyromantyzmu, wykazywał znacznie więcej cech zdefiniowanych przez Johanneta i Maurrasa jako nacjonalitaryzm. Miał typowo nacjonalitarne rozumienie narodu jako wspólnoty etniczno-językowej, a nie historyczno-państwowej; stawial postulat odbudowania państwa według „zasiedlenia ras i narodowości”, wysuwając kryterium przewagi żywiołu etnicznie polskiego, a nie granic historycznych lub naturalnych; był antytradycjonalistyczny $\mathrm{i}$ indyferentny religijnie, w pewnym stopniu nawet antyklerykalny. Jego całkowicie szczerze traktowanym i wysuwanym na plan pierwszy programu (Stronnictwa Demokratyczno-Narodowego, w jego pierwotnej nazwie) składnikiem tożsamości był d e$\mathrm{m}$ o k r a t y z m, rozumiany wprawdzie przede wszystkim jako dążenie do „uobywatelnienia”, a tym samym „unarodowienia”, włościańskich i robotniczych mas ludowych, ale siłą rzeczy również jako zniwelowanie różnic stanowych. Trafnie odczytuje ową intencję badacz narodzin tej ideologii: ,'Żeby Polska była Polską', Polak musiał najpierw stać się demokrata" 29 .

Nacjonalitarysta par excellence był zwłaszcza (i do końca swojego żywota) najstarszy z grona twórców doktryny narodowo-demokratycznej, Jan Ludwik P o p ł a w s k i - szczególnie niechętny szlachcie i ,pańskiemu klerykalizmowi”"30, rozgraniczający „naród pański” i ,naród chłopski"31, „ludoman”, stawiający „,nade wszystko interesy ludu” i opierający się na ,jego poczuciu plemienności, na samorodnych, swojskich podstawach naszego bytu"32. W nieco tylko mniejszym natężeniu dotyczy to jednak również Zygmunta Balickiego i Romana D m o w-

\footnotetext{
${ }^{29} \mathrm{~N}$. Bończa-Tomaszewski, Demokratyczna geneza nacjonalizmu. Intelektualne korzenie ruchu narodowo-demokratycznego, Warszawa 2001, s. 225.

${ }^{30}$ Zob. Pański klerykalizm a wiara chlopska, ,Głos” 1886, nr 3-4.

${ }^{31}$ Zob. J. L. Popławski, Demokratyzacja zasad, „Prawda” 1886, nr 42-43.

${ }^{32}$ Nieporozumienie, „Głos” 1887, nr 3, cyt. za: N. Bończa-Tomaszewski, Demokratyczna geneza nacjonalizmu..., s. 86.
} 
s k i e g o w pierwszej fazie rozwoju ich koncepcji narodu. Wprawdzie już w 1901 r. Dmowski odcinał się od ideologii „praw człowieka” i podkreślał, w bardzo zawiłym wywodzie, że „rdzeniem naszego programu jest nacjonalizm", ale zaraz dodawał, jako rzekomą oczywistość, że nie może on być inny, jak demokratyczny, aczkolwiek ma on ,niewiele wspólnego z całym szeregiem różnych demokratyzmów"33. Jednak przełom w myśleniu Dmowskiego w kierunku nacjonalizmu ,nienacjonalitarnego" rozpoczął się dopiero po podróży do Japonii, czego dowodem było uznanie w Podstawach polityki polskiej, że ,naród jest wytworem bytu państwowego" oraz przekroczenie, obecnego jeszcze w Myślach nowoczesnego Polaka, indywidualistycznego, woluntarystycznego i racjonalistycznego pojmowania więzi narodowej na rzecz tezy, iż ,jednostka, zrośnięta przez pokolenia ze swym narodem, w pewnej szerokiej sferze czynów nie ma wolnej woli, ale musi być posłuszna woli zbiorowej narodu, wszystkich jego pokoleń, wyrażającej się w odziedziczonych instynktach"34 - co jest tezą identyczną $\mathrm{z}$,pewnym determinizmem" Barrèsa. Kresem tej ewolucji była jednak dopiero tzw. katolicko-narodowa faza w myśli Dmowskiego, zainaugurowana pracą Kościól, Naród i Państwo (1927), a jej owocem - w pełni już tradycjonalistyczny nacjonalizm tzw. młodej endecji w latach 30 . Zarówno etniczne rozumienie narodu, jak i demokratyczna zasada „suwerenności narodu”, zostały odrzucone dopiero przez takich teoretyków „młodoendeckiego" nacjonalizmu polskiego, jak sympatyk karlizmu i salazaryzmu - Jędrzej Giertych, ,imperialista idei” - Stanisław Piasecki, przeciwstawiający idei jednorodnego państwa narodowego (która, „wzięta zbyt dosłownie [...] zaszkodziła nam w latach 1918-21"35) koncepcję Wielkiego Narodu - Adam Doboszyński, czy zwolennik monarchii i tradycji Świętego Cesarstwa - Karol Stefan Frycz, podczas gdy ,starzy" endecy, jak Stanisław Grabski, Marian Seyda, czy Wacław Komar-

\footnotetext{
${ }^{33}$ Narodowiec [R. Dmowski], W naszym obozie. Listy do przyjaciót politycznych, ,Przegląd Wszechpolski" 1901, cyt. za: Narodowa Demokracja. Antologia myśli politycznej „Przegladu Wszechpolskiego” (1895-1905), oprac. B. Toruńczyk, Londyn 1983, s. 136 .

${ }^{34}$ R. Dmowski, Podstawy polityki polskiej, „Przegląd Wszechpolski” 1905, cyt. za: ibid., s. 224, 225.

${ }^{35}$ A. Doboszyński, Teoria narodu, Warszawa 1993, s. 63.
} 
nicki, pozostali na pozycjach demokratycznych, więc nacjonalitarnych.

Paradoksalnie zatem, kierunkiem analogicznym do nacjonalizmu Action Française czy Acción Espańola nie był w Polsce ruch narodowo-demokratyczny, lecz monarchistyczny konserwatyzm Stanisława Mackiewicza (Cata), neokonserwatywny imperializm „Myśli Mocarstwowej” i „Buntu Młodych” (Adolf Bocheński), a w pewnym stopniu także, mimo lewicowego rodowodu, obóz piłsudczykowski (,państwowy”). W symbolicznym uproszczeniu można powiedzieć, że „,nacjonalistyczna” była w Polsce „,idea jagiellońska”, a „nacjonalitarna” - ,idea piastowska". Nie znaczy to jednak, że tę drugą należy przypisywać całej endecji: na przykład Dmowski na konferencji w Wersalu bronił granic optymalnego bezpieczeństwa, a nie etnicznych, ale już S. Grabski podczas rokowań pokojowych w Rydze odstępował (zaskoczonym tym) bolszewikom tę samą Mińszczyznę, o którą w Wersalu walczył Dmowski, po to, żeby Polska nie miała „nadmiaru” ludności etnicznie niepolskiej.

$\mathrm{Na}$ przypomnienie zasługuje natomiast, jedyna prawdopodobnie w Polsce, poważna polemika $\mathrm{z}$ koncepcją Johanneta, która podjął pisarz, bliski naonczas ruchowi narodowemu, choć wkrótce oddalony od niego w stronę chadecji i „socjalizmu chrześcijańskiego" - Karol Ludwik K o n i ń s k i. Broniąc ,zasady narodowościowej" wywodził on, iż sprzyjała ona w XIX w. ,sprawie polskiej”, dając podstawę do wysuwania kwestii restytucji państwowości polskiej, podczas gdy zasada legitymistyczna, przyjęta przez Kongres Wiedeński, drogę do niepodległości Polski zamykała. Przypominał nawet incydent, jak to hiszpańscy karliści, rezydujący w Lyonie, cieszyli się z upadku powstania listopadowego i drwili z polskich emigrantów, co wywołało gniew ,nacjonalitarnych" robotników, którzy w odwecie spalili karlistom drukarnię. W konkluzji, Koniński przestrzegał polskich narodowców przed wzorowaniem się na nacjonalizmie „romańskim” i wzywał: „zostańmy więc zasadniczo przy idei demokratyczno-narodowej, wzgardliwie przez nacjonalistę francuskiego ochrzczonej (nacjonalitaryzm)"36.

Wywodom Konińskiego można wszelako przeciwstawić argument, iż „sprawie polskiej” szkodziła nie zasada legitymistyczna, tylko wła-

\footnotetext{
${ }^{36}$ K. L. Koniński, Dialektyka nacjonalizmu (Uwagi o ksiażce René Johanneta), „Przegląd Współczesny", t. XXXII, luty 1930, nr 94, s. 277.
} 
śnie odstępstwa od jej zastosowania: Romanowowie, Hohenzollernowie i Habsburgowie nie byli prawowitymi władcami Polski, a sam fakt likwidacji, istniejącego od wieków państwa polskiego, nie miał precedensu prawno-politycznego w przedrewolucyjnej Europie. Z kolei fakt, że polskie ruchy niepodległościowe przez cały okres porozbiorowy rzeczywiście szukały sojuszników w nacjonalitarnym „obozie demokracji europejskiej", żadnego pozytywnego rezultatu nie przyniósł. Polska odrodziła się dzięki temu, że państwa zaborcze znalazły się po przeciwnych stronach konfliktu w wojnie światowej oraz dzięki wykorzystaniu tej koniunktury przez samorzutne działania polityczne i militarne Polaków po obu stronach konfliktu. Zastrzeżenia Konińskiego poniekąd uprzedził sam Johannet, przestrzegając proroczo, że jeśli odradzająca się Polska będzie opierała swoją „rację bytu” na „zasadzie narodowościowej", to ta natychmiast zostanie obrócona przeciwko niej przez jej własne mniejszości etniczne oraz przez sąsiadów, toteż stoi przed nią zadanie zbudowania wieloetnicznego mocarstwa w naturalnych granicach, gdyż „Polska jest albo imperium, albo niczym (La Pologne est un empire ou rien)" 37 .

Pojęcie nacjonalitaryzmu nie znalazło oddźwięku poza zainteresowanymi tą dystynkcją reprezentantami nacjonalizmu, nad czym należałoby ubolewać, ponieważ dobrze desygnuje ono kardynalne różnice pomiędzy dwiema przeciwstawnymi doktrynami oraz odpowiadającymi im zjawiskami społecznymi.

Należy też zauważyć, że ciagłe mnożenie „niepodległych” państw (których liczba w ciągu ostatniego stulecia wzrosła od około dwóch dziesiątków do około dwóch setek), nieraz zupelnie miniaturowych, jak również ciągle wydłużająca się lista separatyzmów, zgłaszających roszczenia do samoistności politycznej, sprzyjaja $w$ istocie niszczeniu realnej niezawisłości historycznych narodów państwowych i globalizmowi zmierzającemu do ustanowienia faktycznie unitarnego państwa świato-

${ }^{37}$ R. Johannet; op. cit., s. 402. 
wego, nawet gdyby miało ono pozostawić państwom nominalnym symbole suwerenności. Dopóki zatem ,ideologią panująca" zarówno wewnatrz państw, jak i w międzynarodowym ius gentium, pozostaną demokratyczne doktryny „suwerenności narodu" i ,zasady narodowościowej", żadne państwo nie będzie miało teoretycznie przekonywującego argumentu, aby oddalić żądanie „samostanowienia” jakiejkolwiek grupy określającej się jako „narodowość” taka lub inna. Natomiast faktyczna obrona interesu narodowego przez państwa do tego jeszcze zdolne, będzie skrywana pod grubą warstwą makijażu demoliberalnej i humanitarnej „poprawności politycznej”. 